\title{
A theoretical and practical study for the incident solar radiation intensity in the Basrah province (south of Iraq)
}

\author{
Asaad Rehman Saeed Al-Hilphy \\ Food Sciences Dept., Agric. College, Basrah Univesity, Basrah, Iraq
}

\begin{abstract}
A theoretical and practical study was conducted to the incident solar radiation intensity on a horizontal surface and another making an angle $30^{\circ}$ with the horizontal at Basra province, Iraq, during the years 2006 and 2011. The results showed that the intensity of solar radiation increased significantly $(p<0.05)$ as daylight hours increasing reaching a maximum value of $740{ }^{\circ} \mathrm{W} / \mathrm{m}^{2}$ at midday and then decreased after that. This was found to be the trend throughout all months of the two years of our investigation. The intensity of solar radiation varied from one month to another. In addition, the solar radiation falling on the inclined surface is higher than that falling on a horizontal surface. The study also found that there was a significant difference in the intensity of solar radiation between 2006 and 2011. Empirical equations of the fourth order were developed to predict the incident solar radiation on a horizontal, as well as another inclined surface in the Basra province (south of Iraq)
\end{abstract}

Keywords: solar radiation, Basrah, horizontal surface.

\section{INTRODUCTION}

The performance of any solar thermal system depends on the solar radiation available to it. Solar radiation is characterized by it's variability. Even when abundant, it varies during the day, reaching a maximum at noon when the path length through the atmosphere is the shortest. Unless the collector is continuously turned to face the sun, the sun changing altitude and azimuth will reduce the collected heat below the potential maximum. The hours day light also vary seasonally, being the shortest in winter when the need for heat is the greatest [1].

A know ledge of the local solar-radiation is essential for the proper design of building energy systems, solar energy systems and a good evaluation of thermal environment within buildings [2, 3, 4, 5, 6 and 7]. In the design and study of solar energy, information on solar radiation and its components at a give location is very essential. Solar radiation data are required by solar engineers, architects, agriculturist sand hydrologists for many applications such as solar heating, cooking, drying and interior illumination of buildings[8]. Predicted to be the clean energy of tomorrow, solar energy has been in the forefront of energy development in many developed countries and a potential source of energy to developing countries like Malaysia[9].

Madhi [10] Found in the city of Basrah, the measured and calculated solar radiation intensity that incident on the inclined surface $20 \mathrm{deg}$. angle in September 1984 was increased with the increase in daylight hours and up to the maximum value at midday and then down to the end of the day, when daylight hours 9,10 , 12,14 and 16 , the values of the measured solar radiation intensity were $965,1070,945$, and $500 \mathrm{~W} / \mathrm{m}^{2}$ also, the calculated were $770,910,990,850$ and $450 \mathrm{~W} / \mathrm{m}^{2}$ respectively.

Sabbah [11] stated that the highest value of incident solar radiation intensity on the sloped surface by angle of $35 \mathrm{deg}$. in Saudi Arabia in the midday is $1330 \mathrm{~W}$ and its lowest value is $805 \mathrm{~W}$ at four o'clock pm. As mentioned Jensen [12] In Ghana in January 2000 that the incident solar radiation intensity on the sloped surface of $30 \mathrm{deg}$., when daylight hours are 9, 10, 12, 14, $16300,600,820,670$ and $500 \mathrm{~W} / \mathrm{m}^{2}$ respectively. Sebaii [13] in Egypt, are explained that the intensity of solar radiation on 4 August 2000 is reached to $1010 \mathrm{~W} / \mathrm{m}^{2}$ at midday, then decreased to $300 \mathrm{~W} / \mathrm{m}^{2}$ at four o'clock pm. [14 and 15] were confirmed that the incident solar radiation intensity on inclined surfaces was increased with increasing daylight hours and up to a maximum at midday then decreased thereafter.

The average of intensity of solar radiation in Australia is reached to 27.1 and 19.4 on 20 January and 18 March 2000 respectively [16]. Katiyar \& Pandey [17] stated that the maximum of solar radiation intensity in India was $700 \mathrm{~W} / \mathrm{m}^{2}$ at midday in July. Because no detail studies about incidence solar radiation intensity in Basrah province during different times, therefore the aim of present study to investigation the incidence theoretical and practical solar radiation intensity on the Basrah province and study it's changes during different times. 


\section{MATERIALS AND METHODS}

Solar radiation intensity was measured by pyranometer device which manufactured by Kipp and Zonen company, Netherlands, type CM11. Theoretical results were compared with practical also; mathematical equations have been resolved by the Excel program to extract the values of theoretical solar radiation intensity. A factorial experiment with completely randomized design was used. LSD test at 0.05 significantly level was used to compare among treatments means using SPSS software [18]. The monthly average of solar radiation intensity was taken to three different days of each month.

\section{Theoretical solar radiation intensity calculation}

Theoretical solar radiation intensity has been calculated according to [1].

The following empirical equation is recommended for calculation of declination angle:

$$
\delta=23.45 \sin \left[\frac{(\mathrm{N}-80)}{370} 360\right]
$$

Where $\delta$ is Declination angle, $\mathrm{N}$ is the day number in the year .

Equation of time is calculated according to [19].

$$
\mathrm{EQT}=\sum_{\mathrm{k}=0}^{\mathrm{k}=5}\left[\mathrm{~A}_{\mathrm{k}} \cos \left(\frac{2 \pi \mathrm{kN}}{365.25}\right)+\mathrm{B}_{\mathrm{k}} \sin \left(\frac{2 \pi \mathrm{kN}}{365.25}\right)\right]
$$

Where $A_{k}{ }^{\mathrm{s}} B_{k}, k$ are constants and EQT is time of equation, can be obtained from [1 and 20].

Solar time is the time used in all of the sun-angle relationship; it does not with local clock time [21].

$$
\mathrm{ST}=\mathrm{Z} \pm \frac{1}{15}\left(\mathrm{~L}_{\mathrm{st}}-\mathrm{L}_{\mathrm{loc}}\right)+\mathrm{EQT}
$$

Where $\mathrm{L}_{\mathrm{gt}}$ is the standard meridian for the local time zone (in Basrah province is 40 ). $\mathrm{L}_{\mathrm{loc}}$ is the longitude of the location (in Basrah province is 47.78). and the longitudes are in degree, $\mathrm{Z}$ is the local standard time (hour) and ST is the solar time.

Taken positive signal when the city is located east longitude local authorized record in the local time and is negative when the city west of the standard meridian, In regard to the Basrah province taken negative sign. solar hour angle $(\omega)$ Is displacement sun from noon [22].

$$
\omega=\frac{360}{24}(\mathrm{ST}-12)
$$

The zenith angle $\left(\theta_{z}\right)$ and it's complement the sun altitude $(\propto)$ are then given by: (Lunde.1980)

$$
\cos \theta_{z}=\sin \propto=\cos \emptyset \cos \delta \cos \omega+\sin \emptyset \sin \delta
$$

Incident angle $\left(\theta_{1}\right)$ Is the angle of the fall of solar radiation on the surface of the solar collector.

$$
\cos \theta_{1}=\cos (\varnothing-\beta) \cos \delta \cos \omega+\sin (\varnothing-\beta) \sin \delta
$$

Where $(\varnothing)$ is the latitude, $(\delta)$ is the solar declination and $(\beta)$ is the solar collector angle.

Direct normal irradiance $\left(\mathrm{I}_{\mathrm{DN}}\right)$ is calculated from the equation (7):

$$
\mathrm{I}_{\mathrm{DN}}=\operatorname{Aexp} \cdot\left(\frac{-\mathrm{B}}{\cos \theta_{\mathrm{z}}}\right)
$$

Where (B) is the extinction Coefficient and (A) is apparent extraterrestrial solar intensity.

vertical effect for direct radiation falling on a horizontal surface $\left(\mathrm{I}_{h}\right)$ is calculated from the following equation:

$$
\mathrm{I}_{\mathrm{h}}=\mathrm{I}_{\mathrm{DN}} \sin \propto
$$

The incidence diffuse radiation $\left(I_{d}\right)$ falling on the horizontal surface is calculated from the following equation: 


$$
\mathrm{I}_{\mathrm{d}}=\mathrm{c} \times \mathrm{I}_{\mathrm{DN}}
$$

Where $\mathrm{c}$ is a constant.

The total incidence solar radiation $\left(\mathrm{I}_{\mathrm{th}}\right)$ falling on the horizontal surface is:

$$
\mathrm{I}_{\mathrm{th}}=\mathrm{I}_{\mathrm{h}}+\mathrm{I}_{\mathrm{d}}
$$

The direct solar radiation falling on the inclined surface $\left(\mathrm{I}_{t}\right)$ is calculated from the following equation:

$$
\mathrm{I}_{\mathrm{t}}=\mathrm{I}_{\mathrm{DN}} \cos \theta_{1}
$$

The diffuse solar radiation falling on the inclined surface $\left(\mathrm{I}_{\mathrm{dt}}\right)$ is calculated from the following equation:

$$
\mathrm{I}_{\mathrm{dt}}=\mathrm{I}_{\mathrm{h}} \mathrm{F}_{\mathrm{gg}}+\rho\left(\mathrm{I}_{\mathrm{h}}+\mathrm{I}_{\mathrm{d}}\right) \mathrm{F}_{\mathrm{gs}}
$$

Shape Factor $\left(\mathrm{F}_{\mathrm{gg}}\right)$ is used to rectangular surfaces and calculated according to Farber (1977).

$$
\mathrm{F}_{\mathrm{gg}}=\frac{1-\cos \beta}{2}
$$

Angle factor $\left(F_{s s}\right)$ is calculated from equation (14):

$$
\mathrm{F}_{\mathrm{gs}}=\frac{1+\cos \beta}{2}
$$

To calculate the incident direct solar radiation on a horizontal surface will compensate equations $(8,9,13$ and $14)$ in the equation (12):

$$
\mathrm{I}_{\mathrm{dt}}=\left[\mathrm{C} \frac{1+\cos \beta}{2}+\rho(\mathrm{C}+\sin \alpha) \frac{1-\cos \beta}{2}\right] \mathrm{I}_{\mathrm{DN}}
$$

So that the total radiation falling on the inclined surface $\left(\mathrm{I}_{\mathrm{T}}\right)$ be:

$$
\mathrm{I}_{\mathrm{T}}=\mathrm{I}_{\mathrm{t}}+\mathrm{I}_{\mathrm{dt}}
$$

When compensation equations (11) and (15) in equation (16) which can calculate the solar radiation intensity falling on the inclined surface:

$$
I_{T}=I_{D N}\left[\cos \theta_{1}+C \frac{1+\cos \beta}{2}+\rho(C+\sin \alpha) \frac{1-\cos \beta}{2}\right]
$$

\section{RESULTS AND DISCUSSION}

Observed from Tables 1 to 4 , which show the incidence theoretical and practical solar radiation intensity on horizontal surfaces and another making an angle $30^{\circ}$ with the horizontal during the daytime hours for all the months of the years 2006 and 2011. The theoretical and practical solar radiation intensity falling on horizontal surfaces and inclined surfaces with angle of 30 degrees has increased significantly $(\mathrm{P}<0.05)$ with increasing daylight hours and reached a maximum value at 12:00 noon then decreased thereafter to reach the lowest value at four o'clock pm for all months of the year 2006 and 2011. This is due to the Earth's rotation on its axis and as a result change solar angles with daylight hours, which include zenith angle and altitude angle and azimuth angle and reaches the value of the last to zero at midday and to great value at sunrise and sunst as well as changing the angle at hour angle with the daylight hours. These results are agreed with $[10,13,13,14,23$, and 24] Who confirmed that the intensity of solar radiation increases with increasing daylight hours and up to a maximum value at midday then reduced after that.

The reason for the emergence of the differences between the theoretical and practical intensity of solar radiation because the theoretical values based on the intensity of solar radiation outside the atmosphere and the extinction Coefficient and coefficient of solar radiation scattered calculated the cities of the United States by the meteorological stations in which, and the circumstances of those cities are different from the conditions city of 
A theoretical and practical study for the incident solar radiation intensity in the Basrah province

Basra, which led to the occurrence of these differences. As the escalation of light dust in the air reduces the total solar radiation energy hands-on despite the survival of the sky is clear this is the inherent advantage of the summer climate of the southern city of Basra where dust billowing in the afternoon most days. The results showed that the incident solar radiation intensity on a horizontal surface and another making an angle $30^{\circ}$ with the horizontal was vary from one month to another in 2006 and 2011. This is due to the different sun inclination in different seasons. In the summer months the northern end of the axis of rotation of the Earth is tilted toward the sun and be a day longer than the night at each position of the northern hemisphere and the sun is closer to be perpendicular to the surface of the earth. Also noted Lunde [1] that the energy of solar radiation outside the atmosphere changing with the seasons of the year as a result of changing the distance between the sun and the earth. For example, the average intensity of solar radiation falling on a horizontal surface in January 2006 was $530.09 \mathrm{~W} / \mathrm{m}^{2}$ and in the July was $620.7 \mathrm{~W} / \mathrm{m}^{2}$.

The results also showed that the correlation between the theoretical and practical solar radiation intensity was significantly ( $\mathrm{p}<0.05$ ), as well as the coefficient of determination $\mathrm{R}^{2}$ ranged from 0.752255 0.99469 As shown in Table 5. Figures from 1 to 4 show the relationship between the theoretical and practical solar radiation intensity, all the relationships are linear equations for all months of the year 2006.

Table 1. Incidence theoretical and practical solar radiation intensity on horizontal surfaces during the daytime hours in 2006.

\begin{tabular}{|c|c|c|c|c|c|c|c|c|c|c|}
\hline \multirow{2}{*}{$\begin{array}{l}\text { year } \\
\text { months }\end{array}$} & \multirow{2}{*}{$\begin{array}{c}\text { solar } \\
\text { radiation }\end{array}$} & \multicolumn{8}{|c|}{ day hours } & \multirow{2}{*}{ averag } \\
\hline & & 9 & 10 & 11 & 12 & 13 & 14 & 15 & 16 & \\
\hline \multirow{2}{*}{ January } & $I_{\text {thek }}$ & 558.51 & 720.71 & 822.27 & 855.44 & 817.77 & 712.04 & 546.36 & 334.76 & 670.98 \\
\hline & $I_{\text {ipg }}$ & 457.54 & 584.50 & 648.59 & 711.14 & 679.37 & 584.28 & 396.16 & $\mid 179.11$ & 530.09 \\
\hline \multirow{2}{*}{ February } & $I_{\text {hat }}$ & 534.12 & 698.73 & 804.36 & 842.91 & 811.50 & 712.48 & 553.40 & 347.63 & 663.14 \\
\hline & $I_{h p}$ & 392.72 & 558.23 & 693.50 & 753.56 & \begin{tabular}{|l|l|}
738.01 \\
\end{tabular} & 646.82 & 437.08 & 256.96 & 559.61 \\
\hline \multirow{2}{*}{ March } & $I_{\text {hatk }}$ & 525.77 & 681.51 & 779.11 & 810.98 & 774.72 & 673.06 & 513.94 & 311.34 & 633.80 \\
\hline & $I_{h p}$ & 352.78 & 498.71 & 589.15 & 648.43 & 603.15 & 543.36 & 424.36 & 221.22 & 485.15 \\
\hline \multirow{2}{*}{ April } & $I_{\text {hatk }}$ & 508.30 & 648.81 & 732.78 & 753.50 & 709.37 & 603.83 & 445.53 & 249.85 & 581.50 \\
\hline & $I_{\text {hp }}$ & 429.97 & 564.19 & 668.24 & 712.45 & 667.51 & 577.15 & 498.85 & 276.86 & 549.40 \\
\hline \multirow{2}{*}{ May } & $I_{\text {bet }}$ & 491.51 & 624.04 & 701.40 & 717.31 & 670.50 & 564.70 & 408.89 & 219.23 & 549.70 \\
\hline & $I_{\text {hp }}$ & 491.58 & 601.47 & 696.07 & 725.27 & 710.00 & 611.16 & 474.32 & 343.19 & 581.63 \\
\hline \multirow{2}{*}{ June } & $I_{\text {hitk }}$ & 467.14 & 600.55 & 680.42 & 700.11 & 658.07 & 557.67 & 407.50 & 223.20 & 536.83 \\
\hline & $I_{\text {hp }}$ & 551.03 & 635.72 & 731.75 & 685.76 & 730.95 & 663.23 & 579.85 & 399.65 & 622.24 \\
\hline \multirow{2}{*}{ July } & $I_{\text {thot }}$ & 449.60 & 586.99 & 671.92 & 697.27 & 661.03 & 566.11 & 420.57 & 239.21 & 536.59 \\
\hline & $I_{\text {hp }}$ & 469.73 & 626.35 & 723.11 & 779.31 & 753.35 & 672.83 & 544.02 & 396.92 & 620.70 \\
\hline \multirow{2}{*}{ August } & $I_{\text {hakk }}$ & 466.62 & 606.15 & 691.80 & 716.48 & 678.22 & 580.09 & 430.35 & 244.09 & 551.73 \\
\hline & $I_{\text {hp }}$ & 422.94 & 587.25 & 663.67 & 710.21 & 694.19 & 617.10 & 464.95 & 339.49 & 562.48 \\
\hline \multirow{2}{*}{ September } & $I_{\text {hat }}$ & 530.62 & 668.98 & 749.25 & 765.08 & 715.25 & 603.63 & 439.40 & 238.74 & 588.87 \\
\hline & $I_{\text {hop }}$ & 439.92 & 572.45 & 560.94 & 677.01 & 661.22 & 586.09 & 452.03 & 301.89 & 531.44 \\
\hline \multirow{2}{*}{ October } & $I_{\text {hatk }}$ & 591.96 & 726.81 & 799.71 & 805.05 & 742.42 & 616.62 & 437.84 & 223.75 & 618.02 \\
\hline & $I_{\text {hp }}$ & 376.86 & 466.71 & 628.48 & 599.43 & 539.76 & 464.17 & 285.39 & 180.73 & 442.69 \\
\hline \multirow{2}{*}{ November } & $I_{\text {hat }}$ & 620.12 & 757.52 & 831.05 & 835.17 & 769.56 & 639.17 & 454.39 & 232.94 & 642.49 \\
\hline & $I_{\text {L }}$ & 394.52 & 594.35 & 716.35 & 702.73 & 701.09 & 545.82 & 406.10 & 190.82 & 531.47 \\
\hline \multirow{2}{*}{ December } & $I_{\text {Itak }}$ & 604.09 & 753.01 & 838.77 & 854.89 & 800.20 & 678.75 & 499.98 & 279.87 & 663.69 \\
\hline & & 419.90 & 595.09 & 738.34 & 770.16 & 706.00 & 546.41 & 493.97 & \begin{tabular}{|l|}
195.62 \\
\end{tabular} & 558.19 \\
\hline
\end{tabular}

$I_{\text {hnt }}$ : theoretical solar radiation on the horizontal surfaces $\mathrm{W} / \mathrm{m}^{2}$

$I_{h p}$ : practical solar radiation on the horizontal surfaces $\mathrm{W} / \mathrm{m}^{2}$ 
A theoretical and practical study for the incident solar radiation intensity in the Basrah province

Table 2. Incidence theoretical and practical solar radiation intensity on horizontal surfaces during the daytime hours in 2011.

\begin{tabular}{|c|c|c|c|c|c|c|c|c|c|c|}
\hline \multirow{2}{*}{$\begin{array}{c}\text { year } \\
\text { mouths }\end{array}$} & \multirow{2}{*}{$\begin{array}{c}\text { solar } \\
\text { radiation }\end{array}$} & \multicolumn{8}{|c|}{ day hours } & \multirow{2}{*}{ everage } \\
\hline & & 9 & 10 & 11 & 12 & 13 & 14 & 15 & 16 & \\
\hline \multirow{2}{*}{ January } & $I_{\text {hah }}$ & 498.79 & 679.93 & 761.90 & 860.65 & 803.86 & 653.36 & 302.08 & 217.80 & 597.30 \\
\hline & $I_{\text {by }}$ & 558.51 & 720.71 & 822.27 & 855.44 & 817.77 & 712.04 & 546.36 & 334.76 & 670.98 \\
\hline \multirow{2}{*}{ February } & $I_{\text {bh }}$ & 571.79 & 777.95 & 866.35 & 909.83 & 852.95 & 732.74 & 610.19 & 406.17 & 716.00 \\
\hline & $I_{p_{p}}$ & 534.12 & 698.73 & 804.36 & 842.91 & 81150 & 712.48 & 553.40 & 347.63 & 663.14 \\
\hline \multirow{2}{*}{ March } & $I_{\text {sath }}$ & 541.37 & 759.57 & 890.93 & 940.58 & 938.86 & 744.95 & 664.57 & 241.35 & 715.27 \\
\hline & $I_{i p}$ & 525.77 & 681.51 & 779.11 & 810.98 & 774.72 & 673.06 & 513.94 & 311.34 & 633.80 \\
\hline \multirow{2}{*}{ April } & $I_{\text {hin }}$ & 602.20 & 777.95 & 878.64 & 922.13 & 871.36 & 781.59 & 598.11 & 364.97 & 724.62 \\
\hline & $I_{b p}$ & 508.30 & 648.81 & 732.78 & 753.50 & 709.37 & 603.83 & 445.53 & 249.85 & 581.50 \\
\hline \multirow{2}{*}{ May } & $I_{\text {ian }}$ & 553.54 & 716.69 & 792.62 & 823.77 & 760.90 & 690.00 & 501.45 & 382.63 & 652.70 \\
\hline & $I_{i p}$ & 491.51 & 624.04 & 701.40 & 717.31 & 670.50 & 564.70 & 408.89 & 219.23 & 549.70 \\
\hline \multirow{2}{*}{ Jume } & $I_{\text {tha }}$ & 583.96 & 741.19 & 835.63 & 860.65 & 840.67 & 787.70 & 640.40 & 482.70 & 721.61 \\
\hline & $I_{y_{y}}$ & 467.14 & 600.55 & 680.42 & 700.11 & 658.07 & 557.67 & 407.50 & 223.20 & 536.83 \\
\hline \multirow{2}{*}{ July } & $I_{\text {inh }}$ & 687.00 & 879.00 & 996.00 & 1030.00 & 980.00 & 849.00 & 720.00 & 620.00 & 845.13 \\
\hline & $I_{\text {lqp }}$ & 449.60 & 586.99 & 671.92 & 697.27 & 661.03 & 566.11 & 420.57 & 239.21 & 536.59 \\
\hline \multirow{2}{*}{ August } & $I_{\text {iah }}$ & 700.00 & 914.00 & 1028.52 & 1059,81 & 900.00 & 872.28 & 664.28 & 352.05 & 775.88 \\
\hline & $I_{\text {ip }}$ & 466.62 & 650.15 & 791.80 & 816.48 & 678.22 & 680.09 & 530.35 & 244.09 & 607.23 \\
\hline \multirow{2}{*}{ Septer: } & $I_{\text {tath }}$ & 787.05 & 969.06 & 1075.06 & 1032.13 & 893.83 & 780.00 & 680.50 & 366.13 & 822.97 \\
\hline & $I_{l_{p}}$ & 530.62 & 668.98 & 749.25 & 765.08 & 715.25 & 603.63 & 439.40 & 238.74 & 588.87 \\
\hline \multirow{2}{*}{ October } & $I_{\text {tath }}$ & 577.87 & 692.19 & 798.77 & 879.10 & 822.26 & 738.85 & 573.94 & 376.74 & 682.46 \\
\hline & $I_{\text {pq }}$ & 591.96 & 726.81 & 799.71 & 805.05 & 742.42 & 616.62 & 437.84 & 223.75 & 618.02 \\
\hline \multirow{2}{*}{ November } & $I_{\text {tath }}$ & 492.71 & 645.94 & 784.88 & 849.10 & 838.52 & 743.73 & 556.60 & 314.69 & 653.27 \\
\hline & $I_{\text {ip }}$ & 620.12 & 757.52 & 831.05 & 835.17 & 769.56 & 639.17 & 454.39 & 363.67 & 658.83 \\
\hline \multirow{2}{*}{ December } & $I_{\text {tha }}$ & 583.95 & 707.50 & 792.62 & 820.69 & 727.15 & 577.03 & 371.56 & 300.22 & 610.09 \\
\hline & $I_{\varphi q}$ & 604.09 & 753.01 & 838.77 & 854.89 & 800.20 & 678.75 & 499.98 & 346.94 & 672.08 \\
\hline
\end{tabular}

$I_{\text {hin }}$ : theoretical solar radiation on the horizontal sufaces $\mathrm{W} / \mathrm{m}^{2}$

$I_{\text {hp }}$ : practical solar radiation on the horizontal suffaces $\mathrm{W} / \mathrm{m}^{2}$ 
A theoretical and practical study for the incident solar radiation intensity in the Basrah province

Table 3. Incidence theoretical and practical solar radiation intensity on inclined surfaces with angle of 30 degrees during the daytime hours in 2006.

\begin{tabular}{|c|c|c|c|c|c|c|c|c|c|c|}
\hline \multirow{2}{*}{ months } & \multirow{2}{*}{$\begin{array}{c}\text { solar } \\
\text { radiation }\end{array}$} & \multicolumn{8}{|c|}{ day hours } & \multirow{2}{*}{ everage } \\
\hline & & 9 & 10 & 11 & 12 & 13 & 14 & 15 & 16 & \\
\hline \multirow{2}{*}{ Jamuary } & $I_{7 n h}$ & 697.24 & 879.88 & 993.62 & 1030.70 & 988.59 & 870.16 & 683.50 & 395.23 & 817.37 \\
\hline & $I_{T_{p}}$ & 521.77 & 660.88 & 730.49 & 800.06 & 765.28 & 660.88 & 452.13 & 208.71 & 600.03 \\
\hline \multirow{2}{*}{ February } & $I_{\text {nh }}$ & 699.16 & 892.82 & 1016.37 & 1061.35 & 1024.71 & 908.94 & 721.94 & 428.87 & 844.27 \\
\hline & $I_{T_{p}}$ & 469.46 & 660.88 & 817.39 & 886.95 & 869.62 & 765.28 & 521.77 & 313.06 & 663.05 \\
\hline \multirow{2}{*}{ March } & $I_{\text {7n }}$ & 713.38 & 901.73 & 1019.00 & 1057.20 & 1013.74 & 891.56 & 698.99 & 396.59 & 836.52 \\
\hline & $I_{T_{p}}$ & 433.08 & 606.31 & 713.10 & 783.87 & 730.17 & 660.88 & 521.43 & 278.30 & 590.89 \\
\hline \multirow{2}{*}{ April } & $I_{\text {nh }}$ & 685.85 & 854.28 & 954.24 & 978.85 & 926.42 & 800.55 & 609.94 & 317.97 & 766.01 \\
\hline & $I_{T_{P}}$ & 521.77 & 678.31 & 800.07 & 852.24 & 800.06 & 695.70 & 608.74 & 347.85 & 663.09 \\
\hline \multirow{2}{*}{ May } & $I_{7 \mathrm{nh}}$ & 672.24 & 827.07 & 916.58 & 934.92 & 880.89 & 758.03 & 574.32 & 270.59 & 729.33 \\
\hline & $I_{T_{p}}$ & 573.92 & 695.70 & 801.80 & 834.80 & 819.13 & 709.56 & 558.24 & 417.40 & 676.32 \\
\hline \multirow{2}{*}{ Jume } & $I_{7 \mathrm{mh}}$ & 635.08 & 787.57 & 877.79 & 899.94 & 852.61 & 738.83 & 565.88 & 267.33 & 703.13 \\
\hline & $I_{T_{p}}$ & 625.89 & 714.84 & 819.13 & 766.90 & 819.20 & 747.88 & 662.61 & 471.34 & 703.47 \\
\hline \multirow{2}{*}{ July } & $I_{\text {nh }}$ & 621.61 & 780.88 & 878.07 & 906.96 & 865.66 & 756.85 & 587.50 & 288.38 & 710.74 \\
\hline & $I_{T_{p}}$ & 540.48 & 713.02 & 819.20 & 881.75 & 853.95 & 766.98 & 627.79 & 471.28 & 709.31 \\
\hline \multirow{2}{*}{ August } & $I_{\text {Th }}$ & 655.67 & 823.01 & 924.61 & 953.76 & 908.55 & 791.95 & 611.65 & 305.69 & 746.86 \\
\hline & $I_{T_{P}}$ & 506.12 & 695.71 & 782.67 & 836.59 & 819.20 & 732.23 & 558.30 & 419.16 & 668.75 \\
\hline \multirow{2}{*}{ September } & $I_{\text {Th }}$ & 732.57 & 900.84 & 997.78 & 1016.85 & 956.77 & 821.58 & 620.44 & 308.02 & 794.36 \\
\hline & $I_{T_{p}}$ & 646.999 & 834.848 & 815.027 & 983.034 & 962.163 & 857.808 & 669.959 & 461.25 & 778.89 \\
\hline \multirow{2}{*}{ October } & $I_{\text {Th }}$ & 785.05 & 945.78 & 1032.26 & 1038.58 & 964.32 & 814.54 & 599.50 & 285.77 & 808.23 \\
\hline & $I_{T_{P}}$ & 453.94 & 558.30 & 749.63 & 714.84 & 645.26 & 558.30 & 347.85 & 227.84 & 532.00 \\
\hline \multirow{2}{*}{ November } & $I_{7 \mathrm{~m}}$ & 780.08 & 936.66 & 1020.13 & 1024.80 & 950.34 & 801.84 & 589.48 & 284.02 & 798.42 \\
\hline & $I_{T_{p}}$ & 454.29 & 680.06 & 817.45 & 801.80 & 801.80 & 627.87 & 473.08 & 229.58 & 610.74 \\
\hline \multirow{2}{*}{ December } & $I_{7 \mathrm{~m}}$ & 736.50 & 901.23 & 995.69 & 1013.43 & 953.24 & 819.22 & 620.56 & 327.80 & 795.96 \\
\hline & $I_{T_{p}}$ & 469.60 & 660.88 & 817.45 & 852.24 & 782.67 & 608.74 & 556.21 & 226.07 & 621.73 \\
\hline
\end{tabular}

$I_{\text {hat }}$ : theoretical solar radiation on the inclined surfaces $\mathrm{W} / \mathrm{m}$
$I_{\text {hyp }}$ : practical solar radiation on the inclined surfaces $\mathrm{W} / \mathrm{m}^{2}$

Table 4. Incidence theoretical and practical solar radiation intensity on inclined surfaces with angle of 30 degrees during the daytime hours in 2011.

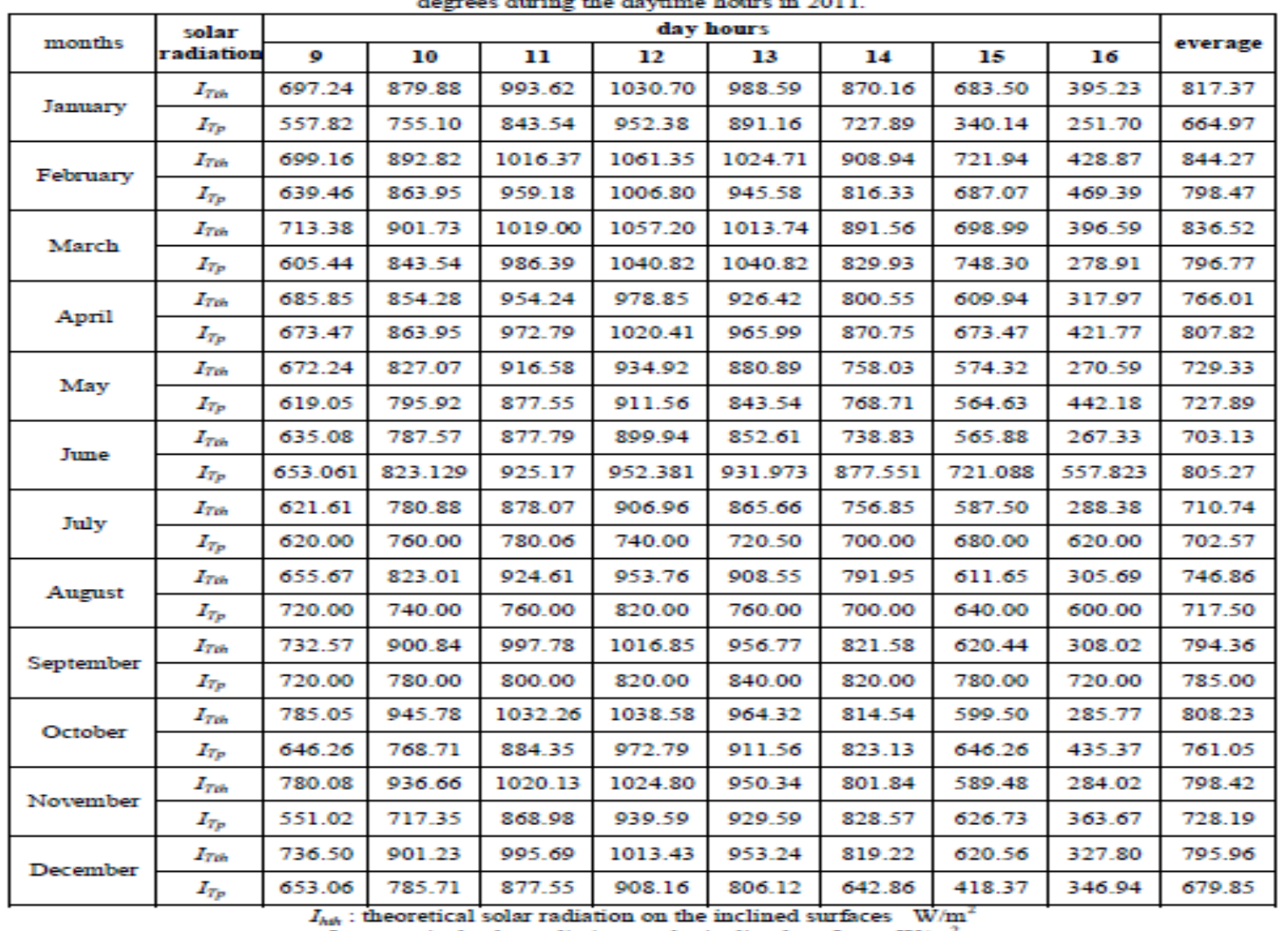

$I_{h a h}$ : theoretical solar radiation on the inclined surfaces $\mathrm{W} / \mathrm{m}$ 
Table 5. The correlation coefficient $\left(\mathbb{R}^{2}\right)$ between Incidence theoretical and practical solar radiation intensity on horizontal surface and inclined surfaces with angle of $30 \mathrm{deg}$.

\begin{tabular}{|l|c|c|c|c|}
\hline \multirow{2}{*}{} & \multicolumn{2}{|c|}{2006} & \multicolumn{2}{c|}{2011} \\
\cline { 2 - 5 } & Horizontal & $\begin{array}{c}\text { inclined } \\
30^{\circ}\end{array}$ & Horizontal & $\begin{array}{c}\text { inclined } \\
30^{\circ}\end{array}$ \\
\hline January & 0.99286 & 0.99469 & 0.96692 & 0.957284 \\
\hline February & 0.988274 & 0.98134 & 0.9942 & 0.990272 \\
\hline March & 0.981994 & 0.97852 & 0.977686 & 0.980066 \\
\hline April & 0.966595 & 0.96234 & 0.99193 & 0.988878 \\
\hline May & 0.978315 & 0.96423 & 0.986728 & 0.971088 \\
\hline June & 0.956898 & 0.95653 & 0.956827 & 0.937612 \\
\hline July & 0.959335 & 0.93505 & 0.96414 & 0.829901 \\
\hline August & 0.968237 & 0.94813 & 0.983334 & 0.921733 \\
\hline September & 0.933968 & 0.92600 & 0.972434 & 0.752255 \\
\hline October & 0.968655 & 0.95906 & 0.940408 & 0.935491 \\
\hline November & 0.956332 & 0.95111 & 0.873959 & 0.886201 \\
\hline December & 0.961394 & 0.95893 & 0.982523 & 0.959767 \\
\hline
\end{tabular}

The relationship between the daylight hours and the intensity of solar radiation falling on the surface of the horizontal and another making an angle $30^{\circ}$ with the horizontal is the equation of the fourth order $I_{T}$ $=a+b_{0} t+b_{1} t^{2}+b_{2} t^{3}+b_{3} t^{4}$, the coefficient of determination between them more than 0.96, as shown in Tables 6 and 7 are show that constants of the equation which governing the relationship between the daylight hours and the intensity of solar radiation.

Table 6. The equations constants which used for prediction of practical solar radiation intensity on horizontal surfaces in 2006 and 2011

\begin{tabular}{|c|c|c|c|c|c|c|c|}
\hline years & months & a & $b_{0}$ & $b_{1}$ & $b_{2}$ & $b_{3}$ & $\mathrm{R}^{2}$ \\
\hline \multirow{12}{*}{2006} & January & 6704.8 & -2578.7 & 359.07 & -20.056 & 0.3808 & 0.9971 \\
\hline & February & 16843 & -6283.5 & 848.03 & -47.839 & 0.9582 & 0.9973 \\
\hline & March & -5550.3 & 1394 & -120.19 & 5.2222 & -0.1091 & 0.9963 \\
\hline & April & -7479 & 2035.4 & -194.99 & 8.9835 & -0.1783 & 0.9877 \\
\hline & May & 14209 & -5204.2 & 702.92 & -39.974 & 0.8116 & 0.9992 \\
\hline & June & -12550 & 4111.4 & -488.58 & 26.456 & -0.5512 & 0.9683 \\
\hline & July & 4825.2 & -2190.4 & 342.08 & -20.843 & 0.4336 & 0.9995 \\
\hline & August & 4558.6 & -2117.3 & 334.34 & -20.561 & 0.4315 & 0.9947 \\
\hline & September & 9665.5 & -3394.3 & 441.38 & -23.847 & 0.452 & 0.9561 \\
\hline & October & 16364 & -6200 & 856.46 & -49.939 & 1.0424 & 0.9779 \\
\hline & November & -8772.8 & 2074.3 & -154.74 & 4.6771 & -0.0575 & 0.9931 \\
\hline & December & -15354 & 4349.6 & -445.46 & 20.984 & -0.3959 & 0.9703 \\
\hline \multirow{13}{*}{2011} & January & 343.08 & -683.31 & 157.07 & -10.74 & -0.3959 & 1 \\
\hline & February & 390.26 & -699.36 & 157.57 & -10.669 & 0.2214 & 1 \\
\hline & March & 425.55 & -693.49 & 155.66 & -10.587 & 0.2212 & 1 \\
\hline & April & 543.81 & -703.83 & 154.93 & -10.59 & 0.224 & 1 \\
\hline & May & 651.74 & -724.06 & 155.97 & -10.649 & 0.2265 & 1 \\
\hline & June & 712.91 & -743.05 & 156.86 & -10.614 & 0.2246 & 1 \\
\hline & July & 735.97 & -755.29 & 157.48 & -10.562 & 0.2218 & 1 \\
\hline & August & -33620 & 10570 & -1225.6 & 63.808 & -1.2641 & 0.9692 \\
\hline & September & 522.52 & -697.16 & 155.55 & -10.719 & 0.2282 & 1 \\
\hline & October & 411.62 & -660.89 & 154.54 & -10.876 & 0.2345 & 1 \\
\hline & November & 16225 & -6196.5 & 873.88 & -51.918 & 1.102 & 0.9978 \\
\hline & December & 8428.6 & -3490.7 & 522.89 & -31.8 & 0.6739 & 0.9994 \\
\hline & January & 343.08 & -683.31 & 157.07 & -10.74 & -0.3959 & 1 \\
\hline
\end{tabular}


A theoretical and practical study for the incident solar radiation intensity in the Basrah province

Table 7. The equations constants which used for prediction of practical solar radiation intensity on inclined surfaces with angle of $30 \mathrm{deg}$. in 2006 and 2011.

\begin{tabular}{|c|c|c|c|c|c|c|c|}
\hline The year & months & $\mathrm{a}$ & $\mathrm{b}_{0}$ & $\mathrm{~b}_{1}$ & $\mathrm{~b}_{2}$ & $\mathrm{~b}_{3}$ & $\mathrm{R}^{2}$ \\
\hline \multirow{8}{*}{} & January & 10366 & -3787.7 & 507.04 & -27.832 & 0.5285 & 0.9975 \\
\cline { 2 - 8 } & February & 19434 & -7241.8 & 976.97 & -55.083 & 1.1025 & 0.9972 \\
\cline { 2 - 8 } & March & -7308.4 & 1909.3 & -175.26 & 8.0225 & -0.1671 & 0.996 \\
\cline { 2 - 8 } & April & -9506.6 & 2649 & -262.21 & 12.403 & -0.2472 & 0.9864 \\
\cline { 2 - 8 } & May & 16540 & -6028.3 & 811.95 & -46.125 & 0.9369 & 0.9991 \\
\cline { 2 - 8 } & June & -13925 & 4588.1 & -547.31 & 29.686 & -0.6179 & 0.9637 \\
\cline { 2 - 8 } & July & 5482.3 & -2463.8 & 383.64 & -23.371 & 0.4872 & 0.9994 \\
\cline { 2 - 8 } & August & 5373 & -2475 & 389.96 & -23.979 & 0.504 & 0.9941 \\
\cline { 2 - 8 } & September & 13980 & -4885.1 & 633.39 & -34.163 & 0.6473 & 0.9523 \\
\cline { 2 - 8 } & October & 19589 & -7400.6 & 1020.5 & -59.444 & 1.2403 & 0.9767 \\
\cline { 2 - 8 } & November & -10619 & 2592.3 & -206.71 & 7.0652 & -0.1015 & 0.9927 \\
\cline { 2 - 8 } & December & -17914 & 5147.3 & -536.82 & 25.71 & -0.4895 & 0.9685 \\
\hline \multirow{5}{*}{ January } & 60855 & -21373 & 2764.8 & -154.2 & 3.1308 & 0.976 \\
\cline { 2 - 8 } & February & 6704.8 & -2578.7 & 359.07 & -20.056 & 0.3808 & 0.9966 \\
\cline { 2 - 8 } & March & -28536 & 8974.4 & -1046.7 & 55.852 & -1.1531 & 0.9966 \\
\cline { 2 - 8 } & April & -4097.4 & 780.58 & -19.867 & -1.1166 & 0.0258 & 0.9992 \\
\cline { 2 - 8 } & May & 5330.8 & -2521.8 & 411.15 & -26.111 & 0.5669 & 0.9913 \\
\cline { 2 - 8 } & June & -5434.6 & 1313.9 & -92.874 & 2.8559 & -0.0451 & 0.9966 \\
\cline { 2 - 8 } & July & -33762 & 10893 & -1275.8 & 65.815 & -1.2648 & 0.9966 \\
\cline { 2 - 8 } & August & 22474 & -7559 & 963.77 & -53.321 & 1.0795 & 0.9677 \\
\cline { 2 - 8 } & September & -2214.5 & 846.53 & -95.189 & 5.1768 & -0.1136 & 0.9835 \\
\cline { 2 - 8 } & October & 18815 & -6684 & 878.34 & -48.628 & 0.9599 & 0.9835 \\
\cline { 2 - 7 } & November & 11544 & -4341.4 & 589.59 & -32.618 & 0.6248 & 0.9998 \\
\hline & December & 36382 & -13129 & 1754.1 & -100.69 & 2.0969 & 0.9981 \\
\cline { 2 - 7 } & January & 60855 & -21373 & 2764.8 & -154.2 & 3.1308 & 0.976 \\
\hline
\end{tabular}

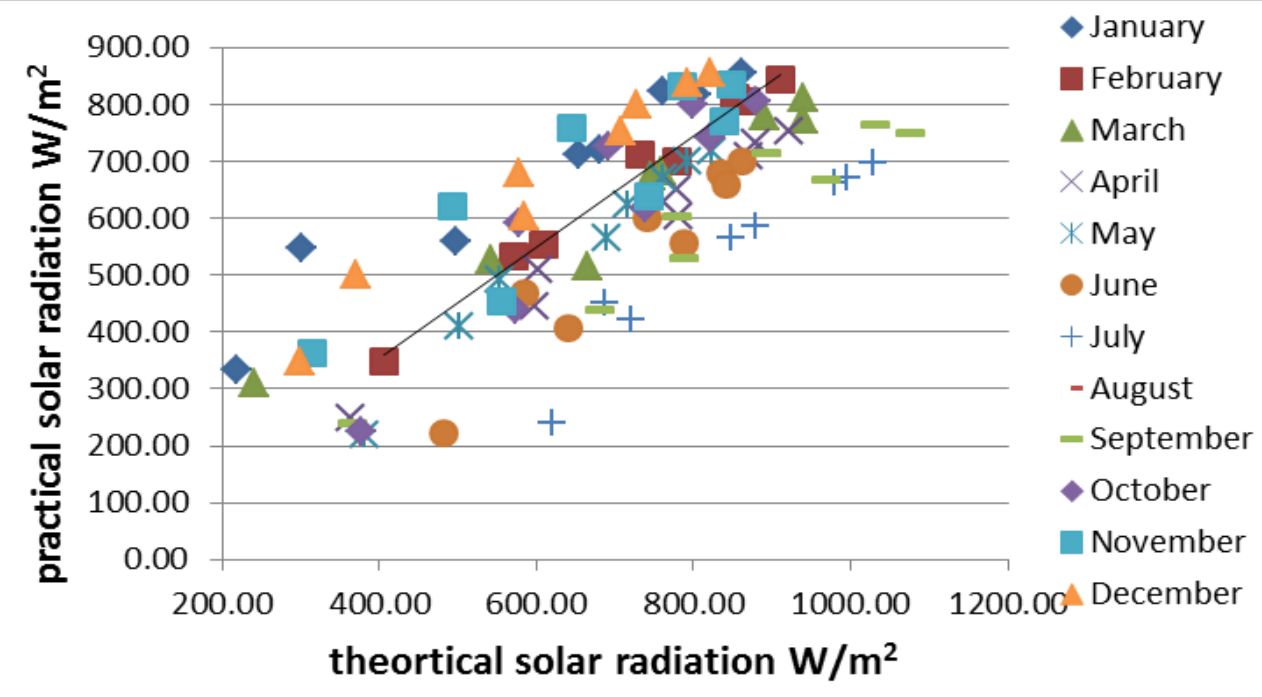

fig. 2: Theoretical solar radiation vs. practical solar radiation at diffrent months in 2011. on the horizontal surfaces. 

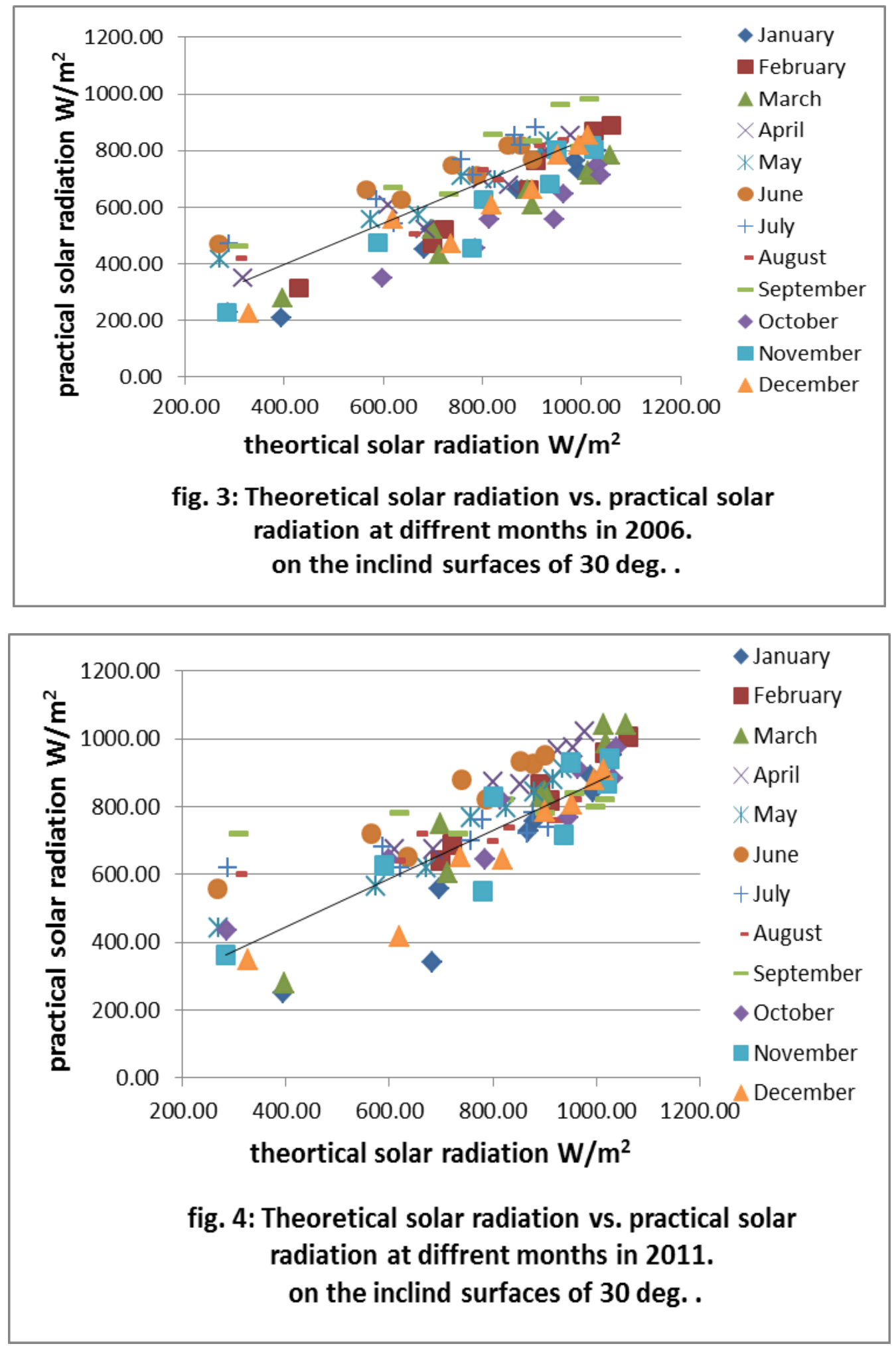

Seen from Figure 5, which shows the average of the theoretical and practical solar radiation intensity falling on a horizontal surface and another making an angle $30^{\circ}$ with the horizontal. Theoretical and practical solar radiation intensity falling on the surface of the inclined angle of 30 degrees was significantly $(\mathrm{p}<0.05)$ higher than those falling on the horizontal surface, and also rate the incidence practical solar radiation intensity falling on a horizontal surface and another on the surface of the inclined angle of 30 degrees in 2011 was highest significantly $(p<0.05)$ of those fallen in 2006. 


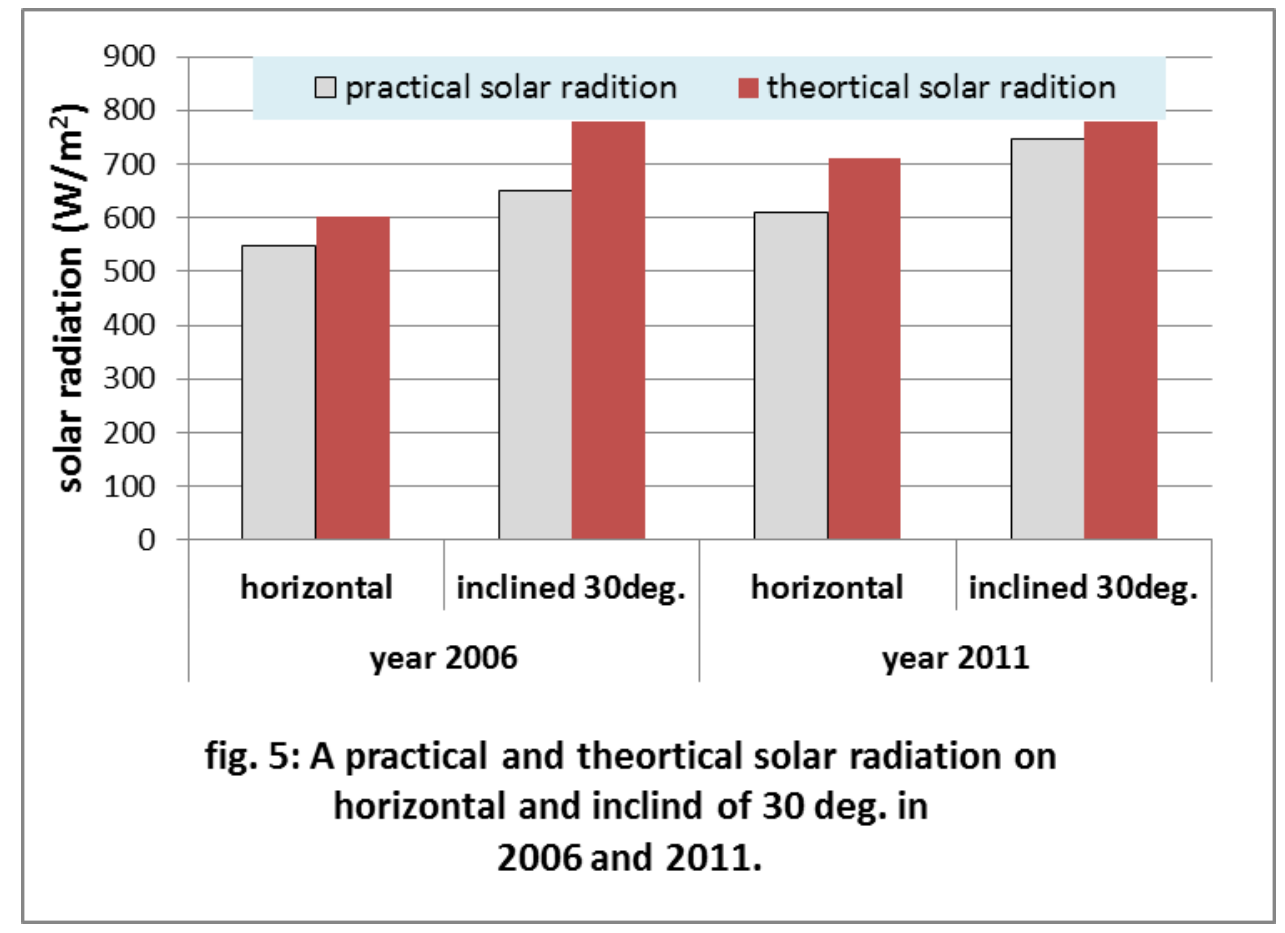

\section{CONCLUSION}

We can conclude from the current study that the intensity of theoretical and practical solar radiation is change with daylight hours and up to highest value at midday. As the intensity of theoretical and practical solar radiation is vary from one month to another. Empirical equations were concluded of the fourth order strongly to predict solar radiation in the southern city of Basra. Intensity of solar radiation in 2011 was higher than in 2006. We recommend conducting subsequent studies in the coming years to identify strongly increase solar radiation in the southern city of Basrah.

\section{REFERENCES}

[1] P. J. Lunde. Solar thermal engineering . Willey, New York . (1980).

[2] Z. Lu, Piedrahita RH, Neto. CDS Generation of daily and hourly solar radiation values for modeling water quality in aquaculture ponds. Transactions of the ASAE, 41(6):1853-9. (1998).

[3] MA. Machler, Iqbal M. A modification of the ASHRAE clear-sky irradiation model. ASHRAE , Transactions, 91(1a):106-15. (1985).

[4] TJ. Cartwright. Here comes the Sun: solar energy from a flat-plate collector. In: Modeling the worldin a spreadsheet-environmental simulation on a microcomputer. London: The Johns Hopkins University Press, p. 121-44. (1993).

[5] J. H. Trujillo. Solar performance and shadow behaviour in buildings - case study with computer modelling of a building in Loranca, Spain. Building and Environment. 33(2-3):117-30. (1998).

[6] ASHRAE. Handbook: HVAC applications. Atlanta (GA): ASHRAE. (1999).

[7] .H.W. Li, J.C. Lam. Solar heat gain factors and the implications for building designs in subtropical regions. Energy and Buildingsz. 32(1):47-55. (2000).

[8] M. J. Ahmad \& G.N. Tiwari. Solar radiation models - review. International Journal of Energy and Enviromental. Vol. 1, 3, pp.513-532. (2010).

[9] S. C. Chua and T. H. Oh, "Review on Malaysia's national energy developments: Key policies,agencies, programmes and international involvements", Renew. Sust. Ener. Rev., 2010, 14, 2916-2925.

[10] S.M. Madhi. Un investigation into solar assisted desiccant-evaporative air conditioning system. MSc. Thesis. Engineering college. Basrah univ. Iraq. . (1985).

[11] M.A. Sabbah .Design and performance of a solar drying system in Riyadh area .J. coll. Agric.King Saud Unv. Vol. 8 No. 1 . pp. 49-76. (1986).

[12] S. Jensen , E. F. Kristensen \& T. Forman .Test of a solar crop dryer . first edition . ISBN : 87- 7756 583 - 5 . Denmark. p. 96 . .(2001).

[13] A.A. Sebaii , S. Abaul-Enein , M.R. Ramadan \& H. EL - Gohary. Experimental investigation of an indirect type natural convection solar dryer . Energy convection and management. Vol. 43 , pp. 22512266 . (2002). 
[14] S. Krauter , \& F. Ochs . An All - in - one solar home system . R10 02 - world climate \& energy events, January $6-11,(2002)$.

[15] C. Coskun ; Z. Oktay, I. Dincer. Estimation of monthly solar radiation distribution for solar energy system analysis. Energy, 36.1319 - 1323. (2011).

[16] D.L. George , M.L. Gupta \& F. Sinon . Drying of macerated lucerne hay in Australia . J. of Candian Biosystems Engineering Vol. 46 . (2004).

[17] A. K. Katiyar, \& C. K. Pandey . Correlation for estimation of hourly solar radiation. International Journal of Energy and Enviromental. Vol. 2, Issue 1, pp.191-198. (2011).

[18] SPSS. Spss statistical package for window ver. 17. O. Chicago : Spss, Inc. (2009).

[19] L.O. Lamm . A new expression for the equation of time. Solar Energy . 26: 465 . (1980).

[20] A. R. Al-Hilphy. Food Engineering in Solar Energy. Al-Zahra press. Basrah, Iraq.p 400.,.(2010).

[21] J.A. Duffie \& W.A. Beckman . Solar Engineering of thermal, Processes, Willey - Interscience , New York . (1980).

[22] E.A. Farber \& A.C. Morrison . Clear - Dry design values. In applications of solar energy, for heating and cooling of buildings, edited by Jordan, I.C. \& Liu , B.Y.H. , ASHRAE, GRP 170 . (1977) .

[23] S. Singh , P.P.Singh , \& S.S. Dhaliwal . Multi-shelf portable solar dryer . Renewable energy 29, pp. $753-$ 765 . (2004)

[24] A. R.S. AL-Hilphy, S. M. H. Al-Shatty and A. A.Gahffr. Design and manufacturing of a vacuum solar dryer for fish and study its efficiency. Basrah Reseach J.1 (39), pp: 40-59. (2013). 